\title{
THE RELATIONSHIP BETWEEN MERGER \& ACQUISITION AND BANK RISKS
}

\author{
Hussein Ahmad Bataineh ${ }^{1 \mathrm{i}}$, \\ Raqiya Ali Al Balushi², \\ Sulaiman Salim Al Harthy ${ }^{3}$ \\ ${ }^{1}$ Research Scholar, \\ Finance Department, \\ Jordan University, \\ Amman, Jordan \\ 2Internal Auditor, \\ Bank Muscat, \\ Oman \\ ${ }^{3}$ Senior Islamic Banking Analyst, \\ Central Bank of Oman, \\ Oman
}

\begin{abstract}
:
This study aimed to investigate the relationship between merger \& acquisition and bank risks. The sample of the study consisted of 55 commercial banks sector listed on Orbs from (2011-2016). The results of the study showed that there is no relationship between the net benefit and bank's risk, and also there is no relationship between the capital ratio and bank's risk, and also there is no relationship between the equity ratio and bank's risk, that there is a relationship between the capital ratio and bank's risk. Generally, we note no relationship between the merger \& acquisition and banks risk. The recommended of the study recommended that the most important of which are the concentration of banks in general on the level of losses they suffer due to the loans extended to customers and other institutions.
\end{abstract}

JEL: G10; G21; G15

Keywords: merger \& acquisition, bank risk, orbs

\section{Introduction}

There is a rising significance of mergers and acquisitions in financial services section as a result of growing globalization and addition on global financial markets in the global economy. These days, the research question arises how significant, profitable or risky

i Correspondence: email hussainsalbataineh@gmail.com 
these ways of gaining and investing capital. Therefore, ways are being determined to quantify the significant indicators, which most of all influence the success rate of mergers and acquisitions in the banking industry. Authors from the European Central Bank, in their empirical study of 2004, examined the impacts of EU bank's strategic similarities on post-merger performance with a use of the regression analysis. Several financial indicators were involved in the analysis with the aim to define strategic features of banks involvement in domestic and cross-country mergers in the EU in relation to their performance. These indicators included a measuring of financial performance, structure of assets and liabilities, capital structure, liquidity, risks, profitability, financial innovation and efficiency (PWC, 2013).

So, the study of Sofrankova (2013) showed common features for the banking sectors in other countries of the EU in context of global crisis and proceeding impacts of global crisis based on existence of common relationships and dependences. In this study, the researchers will investigate the relationship between the merger \& acquisition and commercial banks risk.

\section{Statement of the Problem}

Mergers have extend interested in the nearly all important means of attaining higher performance which is the eventual objective of any firm, as well as banks. Many studies carried out in the area of M\&A have recognized mismatched results. Mergers and acquisitions continue to be a highly popular form of corporate growth in today's banking industry world in excess of. The problem of the study can be formulated with many questions:

Question One: Is there a relationship between the bank's Merger \& Acquisition and bank's risks? This study has a sub-questions such as:

- Is there a relationship between the net benefit ratio and bank's risk?

- Is there a relationship between the capital ratio and bank's risk?

- Is there a relationship between the interest bank ratio and bank risk?

- Is there a relationship between the equity ratio and bank risk?

Question Two: Is there a relationship between the Bank size and bank's risks?

Question Three: Is there a relationship between net income and bank's risks?

\subsection{Objectives of the Study}

This study aims to:

1) Investigate the relationship between the bank's Merger \& Acquisition and bank's risks.

2) This study has sub-objectives such as:

- Investigate the relationship between the net benefit ratio and bank`s risk.

- Investigate the relationship between the capital ratio and bank's risk.

- Investigate the relationship between the interest bank ratio and bank risk.

- Investigate the relationship between the equity ratio and bank risk.

3) Investigate the relationship between the bank size and bank's risks. 
4) Investigate the relationship between net income and bank's risks.

\subsection{Importance of the Study}

This study is important because of the concentration and importance of mergers and acquisitions. Accordingly, this study will be of great benefit for many banks that have been acquired and merged with banks and other financial institutions. More importantly, this study will provide several results that illustrate the nature of the relationship between mergers and acquisitions risk in banks, as well as what the study will offer to many recommendations that improve the performance of the banks that have been acquired.

\subsection{Hypotheses of the Study}

The study includes several hypotheses:

First Hypothesis (H1): There is a relationship between the bank's merger \& acquisition and bank's risks. This study has sub-hypotheses such as:

$\left(\mathbf{H}_{1.1}\right)$ : There is a relationship between the net benefit and bank's risk.

(H1.2): There is a relationship between the capital ratio and bank's risk.

$\left(\mathbf{H}_{1.3}\right)$ : There is a relationship between the interest bank ratio and bank risk.

(H1.4): There is a relationship between the equity ratio and bank risk.

Second Hypothesis (H2): There is a relationship between the bank size and bank's risks.

Third Hypothesis (H3): There is a relationship between net income and bank's risks.

\section{Literature Review}

Marembo (2012) aimed to investigate the effect of mergers and acquisition on the financial performance of commercials banks in Kenya. The sample of the study consisted of 27 commercial banks in Kenya. The results of the study showed that the merger \& acquisition, the financial institutions became more financially sound and profitable as the market share of the new company improved tremendously.

Zisi (2014) examined the impact of mergers \& acquisitions on shareholder's wealth in the UK Banking industry. The study used many statistical methods such as description analysis and regression. The study found that interesting outcomes about the movement of target and bidder shareholders' wealth, and also found that a high positive reaction to the event on the day of the announcement.

Kiselakova and Sofrankova (2015) investigated the impact and risks of mergers and acquisitions on entrepreneurship in banking and finance. The sample of the study included all banks in Slovakia from (1997-2011) and used many statistical methods such as descriptive statistical. The study found that risks it is still necessary to apply more effective models of risk regulation, stiffer internal rating systems, and quality techniques to mitigate financial risks, implement proactive monitoring and strategy risk prevention, 
streamline the management of quality bank credit transactions, and minimize bank's credit risk.

Novickytė \& Pedroja (2015) aimed to investigate the relationship between mergers and acquisitions and financial system development in small open economy. This study found that Mergers and acquisitions in banking are motivated by factors of tangible and intangible synergy. The input motives, to entering interested in this type of transaction dependent on the economic situation of any country. Particularly, at times of depression banks be liable to merge driven by the assure of financial constancy, thus far frequently deal is made in search of economic benefits, which comprise return to and security of shareholders.

Masud (2015) did a study that aimed to investigate to effect of merger and acquisition on financial performance. The sample of the study consisted of 3 banks to the period from 2006-2012. The study showed that return on assets of two banks was increased and one bank return on asset was decreased after the merger and acquisition, but as compared to averages of two institutions the results was first fall below the merged year typical but after that it become improved.

Joash \& Njangiru (2015) tackled the impact of mergers \& acquisitions on financial performance. The sample of the study consisted of 14 commercial banks in Kenya. This study found that there is effect mergers and acquisitions on financial performance so the merger and acquisition rising the value of the shareholders' through increasing the demand and as a result the price of the organizations shares in the stock.

Abdulazeez et al., (2016) investigated the effect of merger and acquisition on the financial performance of deposit money banks in Nigeria. The sample of the study included from 25 banks to the period from (2002-2008). This study found that financial performance leading to improved financial efficiency owing to merger and acquisition. The result of this study found that merger and acquisitions in the financial system have enhanced considerably the financial performance of nearly all banks in Nigeria.

\section{Methodology of the Study}

\subsection{Population and Sample of the Study}

The population of the study included all firms listed on (Orbs), and the sample of the study consisted (55) Commercial banks sector listed on Orbs from (2011-2016).

\subsection{Variables of the Study}

a. Independent Variable: Mergers and Acquisition.

b. Dependent Variable: Bank of Risk.

c. Control Variables: Bank Size, Equity Ratio.

\subsection{Model of the Study}

We design the model of the study of the following:

$$
\text { B.R }=\alpha+\alpha_{1} \mathrm{NCO}+\alpha_{2} \text { C. R }+\alpha_{3} \text { E.R }+\alpha_{4} \mathrm{I} . \mathrm{B}+\alpha_{5} \mathrm{~T} . \mathrm{A}+\alpha_{6} \mathrm{~N} . \mathrm{I}+\mathrm{e}
$$


Where:

B.R $=$ bank risk.

$\mathrm{A}=$ Alpha, $\alpha 1, \alpha 2, \alpha 3 \ldots \ldots \ldots \alpha$.

$\mathrm{NCO}=$ Net Inc Benefit.

C.R $=$ Capital ratio.

E. $R=$ Equity Ratio.

I.B = Interest bank Ratio.

T.A = Bank Size (Total Assets).

N.I = Net Income.

$\mathrm{E}=$ error term.

\subsection{Resources of the Study}

All data of the study was collected through reference to many previous studies, scientific journals, master's and doctoral dissertations related to the subject of the study, in addition to all the websites specialized in the subject matter of the study and the London Stock Exchange.

\subsection{Statistical Method}

All data of the study was collected later, and then entered into the statistical analysis program SPSS and access to many statistical methods, such as:

- Description Statistical: Includes mean and Standard Deviation, and also minimum and maximum to all variables.

- Regression: This is method test of all hypotheses, so the researchers rejected and accepted all hypotheses from significant.

- Correlation: This is method test of correlation between all variables of the study.

\subsection{Analysis of the study and Test Hypotheses}

This section included analysis of all the study data. All variables of the study were analyzed from independent, dependent and control variables. All the hypotheses of the study were examined and the correlation between all variables was tested.

\subsection{Descriptive Statistics}

This statistical method helps to test and describe all the variables of the study, where a table was developed for all the variables and give the mean arithmetic and standard deviation and the highest and lowest value for all variables. 
Table 1: Descriptive Statistics to all variables

\begin{tabular}{|l|c|c|c|c|c|}
\hline Variables & $\mathbf{N}$ & Minimum & Maximum & Mean & Std. Deviation \\
\hline NCO & 306 & $-6.8371 \mathrm{E} 2$ & 444.6310 & $1.741458 \mathrm{E} 1$ & 91.2728861 \\
\hline Capital & 306 & .0000 & 31.4000 & $1.493763 \mathrm{E} 1$ & 5.6128085 \\
\hline Interest & 306 & .0000 & 571.7770 & $9.358433 \mathrm{E} 1$ & 82.8807559 \\
\hline T.A & 306 & .0000 & $2.8001 \mathrm{E} 9$ & $6.282862 \mathrm{E} 8$ & $5.8794756 \mathrm{E} 8$ \\
\hline Equity & 306 & $-7.9903 \mathrm{E} 6$ & $3.0084 \mathrm{E} 8$ & $3.623783 \mathrm{E} 7$ & $4.0786742 \mathrm{E} 7$ \\
\hline N.I & 306 & $-2.5323 \mathrm{E} 7$ & $9.6554 \mathrm{E} 6$ & $1.105785 \mathrm{E} 6$ & $3.6298900 \mathrm{E} 6$ \\
\hline Loans & 306 & 0 & 21 & 3.14 & 3.278 \\
\hline Valid N (listwise) & 306 & & & & \\
\hline
\end{tabular}

The above table shows:

- The calculation of the NCO variable was 1.74. This indicates that the commercial banks in most of the world countries in the sample of the study have a good level of total return by comparing the highest value of these banks to (444.63) (-6.83). The standard deviation of this variable was 91.27, indicating a difference between the commercial banks in relation to their total return.

- The ratio of the "Capital Ratio" (1.49) to the mean is that commercial banks have a good level of capital compared to the assets they own. This can be confirmed by comparing this value with the highest value of this variable which reached (31.40) while the lowest value (0), and the standard deviation of this variable (5.61), which indicates that there is a difference between commercial banks in the sample study for this variable.

- The ratio of "Interest Rate" Equal (9.35). This indicates that the commercial banks of the sample have a good rate of interest rate on loans granted to institutions and customers. This indicates that the highest value of this variable which reached (571.77) (82.88). This indicates that there is a difference between the commercial banks in the sample of the study in terms of the interest rate it owns.

- The ratio of total assets to (6.2) indicates that the international commercial banks of the sample have a good level of their own assets so that they can withstand the risks they are exposed to. This indicates that the highest value of (2.80) while the lowest value reached (0), with a standard deviation of (5.87), indicating that there is a difference between commercial banks in terms of the level of assets they own.

- The ratio of "Equity Ratio" to (3.62) indicates that international commercial banks have a good level of ownership compared with their assets. This percentage is indicated by the highest value of ownership (3.0) 7.99). The standard deviation (4.07) is a sign that there is a difference between the international commercial banks of the sample of the study in terms of ownership level.

- The mean of Net Income equal (1.10), which indicates that international commercial banks have a good profit level by comparing this value with the highest value owned by these banks (9.65) while the lowest value (-2.53) While the standard deviation was (3.62), indicating that there is a significant difference between the international commercial banks in terms of their annual profits. 
- The mean of the variable "Loans" equal (3.14), which indicates the level of loans granted by the international commercial banks of the sample of the study to others, which have losses, and it is clear to us that this ratio is high, compared to the highest value, which amounted to (21) while (3.27), indicating that there is a difference between the international commercial banks in terms of the losses suffered by the loans granted to clients and institutions.

\subsection{Test of Hypotheses}

In order to test hypotheses, a regression analysis method was used, in which all hypotheses were tested and accepted according to the statistical significance level.

Table 2: Test of Hypotheses

\begin{tabular}{|c|c|c|c|c|c|}
\hline \multirow[t]{2}{*}{ Model } & \multicolumn{2}{|c|}{ Unstandardized Coefficients } & \multirow{2}{*}{$\begin{array}{c}\text { Standardized Coefficients } \\
\text { Beta }\end{array}$} & \multirow[t]{2}{*}{$\mathrm{T}$} & \multirow[t]{2}{*}{ Sig. } \\
\hline & B & Std. Error & & & \\
\hline (Constant) & 4.153 & .530 & & 7.841 & .000 \\
\hline $\mathrm{NCO}$ & .000 & .002 & $-.026-$ & $-.484-$ & .629 \\
\hline CAPITAL & $-.002-$ & .031 & $-.004-$ & $-.077-$ & .939 \\
\hline INTEREST & $-.009-$ & .002 & $-.226-$ & $-4.150-$ & .000 \\
\hline T.A & $2.451 \mathrm{E}-12$ & .000 & .000 & .007 & .994 \\
\hline Equity & $6.329 \mathrm{E}-9$ & .000 & .079 & 1.187 & .236 \\
\hline N.I & $-3.264 \mathrm{E}-7$ & .000 & $-.361-$ & $-6.326-$ & .000 \\
\hline
\end{tabular}

\subsubsection{Dependent Variable: Bank Risk}

The following table shows:

First Hypothesis (H1): There is a relationship between the bank's merger \& acquisition and bank's risks. This study has a sub-hypotheses such as:

$\left(\mathbf{H}_{1.1}\right)$ : There is a relationship between the net benefit and bank's risk.

The significant of this hypothesis equals (0.629) it is more than statistical significance (0.05), therefore it can be inferred that there is no relationship between the net benefit and bank's risk, so we reject this hypothesis and accept alterative hypothesis that states there is no relationship between the net benefit and bank's risk".

(H1.2): There is a relationship between the capital ratio and bank's risk.

The significant of this hypothesis equals (0.939) it is more than the statistical significance (0.05), so Therefore it can be inferred that no there is no relationship between the capital ratio and bank's risk, so we reject this hypothesis and accept alterative hypothesis that states there is no relationship between the capital ratio and bank's risk".

( $\left.\mathbf{H}_{1.3}\right)$ : There is a relationship between the interest bank ratio and bank risk.

The significant of this hypothesis equals (0.000) it is less than the statistical significance (0.05), so, therefore, it can be inferred that there is relationship between the capital ratio and bank's risk.

(H1.4): There is a relationship between the equity ratio and bank risk.

The significant of this hypothesis equals $(0.236)$ it is more than the statistical significance (0.05) therefore, it can be inferred that there is no relationship between the equity ratio 
and bank's risk, so we reject this hypothesis and accept alterative hypothesis that states there is no relationship between the equity ratio and bank's risk".

Second Hypothesis (H2): There is a relationship between the bank size and bank's risks. The significant of this hypothesis equals $(0.994)$ it is more than the statistical significance (0.05), therefore it can be inferred that there is no relationship between the bank size and bank's risk, so we reject this hypothesis and accept alterative hypothesis that states there is no relationship between the banks size and bank's risk".

Third Hypothesis (H3): There is a relationship between net income and bank's risks. The significant of this hypothesis equals (0.000) it is less than the statistical significance ( 0.05 therefore, it can be inferred that there is a relationship between the net income and bank's risk.

\section{Conclusion}

This study aimed to investigate the relationship between merger \& acquisition and banks risk. So, the results of the study there is no relationship between the net benefit and bank's risk, and also there is no relationship between the capital ratio and bank's risk, and also there is no relationship between the equity ratio and bank's risk, but there is relationship between the capital ratio and bank's risk, so in general we note no relationship between the merger \& acquisition and banks risk, but to anther variable we note that there is no relationship between the banks size and bank's risk but that there is a relationship between the net income and bank's risk.

\subsection{Recommendation}

According to the results of the study, a number of recommendations can be made, the most important of which are the concentration of banks in general on the level of losses they suffer due to the loans extended to customers and other institutions. The establishment of rules and rules that limit and reduce the risks to banks, Commercial banks, in terms of the risks they are exposed to, have conducted future studies on another group of banks in a different period of time.

Mergers have extend interested in the nearly all important means of attaining higher performance which is the eventual objective of any firm, as well as banks. Many studies carried out in the area of M\&A have recognized mismatched results. Mergers and acquisitions continue to be a highly popular form of corporate growth in today's banking industry world in excess of.

\section{Conflicts of Interest}

The authors declare no conflict of interests.

\section{About the Authors}

Hussein Ahmad Bataineh is working in Banking sector since 2016. He has a good knowledge in different departments in Banking sector. Regarding to the education, he got MSC in Banking and Finance Bangor University (United Kingdom) Master of Science 
- Banking and Finance in July 2019, achieving an average total mark of 76\%, with a degree classification: Distinction. BSC in Finance Bachelor's degree in Finance from University of Jordan January 2016. During his education and carer journey he was awarded: 1. Academic excellence certificate from Bangor University 2. Award from United Nations Relief and Works Agency (UNRWA) for effective participation in helping Syrian refuges. Raqiya Ali Al Balushi: I held various positions in Bank Muscat with the Internal Auditor position as the latest one. I had worked in the human resources department, which provided me knowledge on human behaviour. I am interested in fully grasping the best approaches in interacting with employees to harness them potential, promote their growth, and make them assets of the organization. As an internal auditor, I understand the financial aspect of the business operation with a perspective of human resources management to align the capital and the workforce. I have worked as an internal auditor since 2015. In between responsibilities in Bank Muscat, I pursued my Master's degree in banking and finance from Bangor University in the United Kingdom with Distinction. The experience enriched knowledge in audits, control points, deviations, and action plans. I conducted special audits and investigations on request of the senior management or the Board of Directors.

Sulaiman Al Harthy: Senior Islamic Banking Analyst at Central Bank of Oman.

\section{References}

Beccalli, E. and Frantz, P. (2015). M\&A operations and performance in banking, Elena Beccalli, Accounting and Finance Department, London School of Economics and Political Science, Houghton Street, London WC2A 2AE.

Joash, G. and Njangiru, M. (2016). The Effect of Mergers and Acquisitions on Financial Performance of Banks (A Survey of Commercial Banks in Kenya), Internal national Journal of Innovative Research and Development, Vol. 4, Issue. 8, PP. 101-114.

Kiselakova, D. and Sofrankova, B. (2015). Effects and Risks of Mergers and Acquisitions on Entrepreneurship in Banking and Finance: Empirical Study from Slovakia, Review of European Studies, Vol. 7, No. 7, PP. 23-35.

Marembo, J. (2012). The Impact of Mergers and Acquisition on the Financial Performance of Commercials Banks in Kenya, Master Thesis, University of Nairobi, Nairobi, Kenya.

Masud, N. (2015). Impact of Merger and Acquisition on Financial Performance of Banks: Evidence from Pakistan, Research Journal of Recent Sciences, Vol. 4, No. 5, PP. 108113.

Novickytè, L. \& Pedroja, G. (2015). Assessment of Mergers and Acquisitions in Banking on Small Open Economy as Sustainable Domestic Financial System Development, Economics, Vol. 8, No. 1, PP. 72-88.

PWC. (2013). Sharing deal insight European Financial Services M\&A news and views. Retrieved from http://www.pwc.com/en GX/gx/financial-services/european- 
mergers-acquisitions-industry-trends/assets/pwc-sharing-deal-insight-europeanfinancial-services-m-and-a-news-and-views-v2-pdf.

Sofrankova, B. (2013). An analytical view on development of mergers and acquisitions in the world and in the Europe. Exclusive Journal: Economy \& society \& environment, $1(1), 14-22$.

Zisi, S. (2014). Mergers and Acquisitions in the UK Banking Industry and their Impact on the Shareholders' Wealth, Master Thesis, Tilburg University, Tilburg. applied to their work. Under the terms of this license, no permission is required from the author(s) or publisher for members of the community to copy, distribute, transmit or adapt the article content, providing a proper, prominent and unambiguous attribution to the authors in a manner that makes clear that the materials are being reused under permission of a Creative Commons License. Views, opinions and conclusions expressed in this research article are views, opinions and conclusions of the author(s). Open Access Publishing Group and European Journal of Economic and Financial Research shall not be responsible or answerable for any loss, damage or liability caused in relation to/arising out of conflict of interests, copyright violations and inappropriate or inaccurate use of any kind content related or integrated on the research work. All the published works are meeting the Open Access Publishing requirements and can be freely accessed, shared, modified, distributed and used in educational, commercial and non-commercial purposes under a Creative Commons Attribution 4.0 International License (CC BY 4.0). 